Dessie, Enyew Adgo, Deckers, J., Nyssen, J., 2013. Geomorphology of the Lake Tana basin, Ethiopia. Journal of Maps, 9(3), 431-437.

\title{
Geomorphology of the Lake Tana basin, Ethiopia
}

Ludwin Poppe ${ }^{\mathrm{a}}$, Amaury Frankl ${ }^{\mathrm{a}}$, Jean Poesen ${ }^{\mathrm{b}}$, Teshager Admasu ${ }^{\mathrm{a}, \mathrm{c}}$, Mekete Dessie ${ }^{\mathrm{d}, \mathrm{e}}$, Enyew Adgo ${ }^{\mathrm{c}}$, Jozef Deckers ${ }^{\mathrm{b}}$ and Jan Nyssen ${ }^{\mathrm{a} *}$

${ }^{a}$ Department of Geography, Ghent University, Ghent, Belgium; ${ }^{b}$ Department of Earth and Environmental Sciences, KU Leuven, Leuven, Belgium; ${ }^{c}$ College of Agriculture \& Environmental Sciences, Bahir Dar University, Bahir Dar, Ethiopia; ${ }^{d}$ School of Civil \& Water Resources Engineering, Bahir Dar University, Bahir Dar, Ethiopia; ${ }^{e}$ Laboratory of Hydrology and Water Management, Ghent University, Ghent, Belgium

(Received 29 August 2012; Resubmitted 25 March 2013; Accepted 26 April 2013)

The geomorphological map of the Lake Tana basin $\left(15,077 \mathrm{~km}^{2}\right.$, Nile basin, Ethiopia) presented in this paper was prepared from fieldwork data, maps and satellite data that were processed with a geographic information system (GIS). It contains four major components: (i) hydrography, (ii) morphology and morphometry, (iii) materials and (iv) processes at a scale of 1:500,000. The geomorphological setting of the basin consists of lavas that erupted from fissures or (shield) volcanoes during the Tertiary and Quaternary eras, were uplifted and eroded primarily by water. Lake Tana emerged through a combination of a lava barrier blocking the Blue Nile to the south and by epirogenetic subsidence. When the lake reached its maximum extent, extensive lacustrine plain (e.g. Fogera and Dembia plains) were created, river valleys and basins were filled with sediment and higher lying topography was eroded. Today, the lake plays a lesser role in landscape formation because of a decreased extent $\left(3041 \mathrm{~km}^{2}\right)$ compared to the ancient maximum $\left(6514 \mathrm{~km}^{2}\right)$. Dominant processes today are fluvial and subaerial. Recent (1886-2010) changes in the lake coastline are small with the exception of the delta formed by Gilgel Abay, which has increased disproportionally over the last 15 years. This indicates a large input of sediment which is mainly due to rivers flowing through Quaternary lavas. The recent sediment input increase is most probably related to human induced land-use changes.

Keywords: Lake Tana; geomorphology; lake level fluctuation; Blue Nile; Ethiopia; Gilgel Abay

\section{Introduction}

Lake Tana (3041 km², $1785 \mathrm{~m}$ a.s.l.) is the largest lake in Ethiopia. It is situated in the northwestern Ethiopian highlands, and is fed by numerous seasonal rivers and four permanent rivers: Megech, Rib, Gumara and Gilgel Abay (Figure 1). The outlet of the lake at its southern tip yields the Blue Nile. The lake has a high ecological value and its water is used for many purposes, including irrigation, hydropower, fishing, transportation and tourism. Sustainable use of 

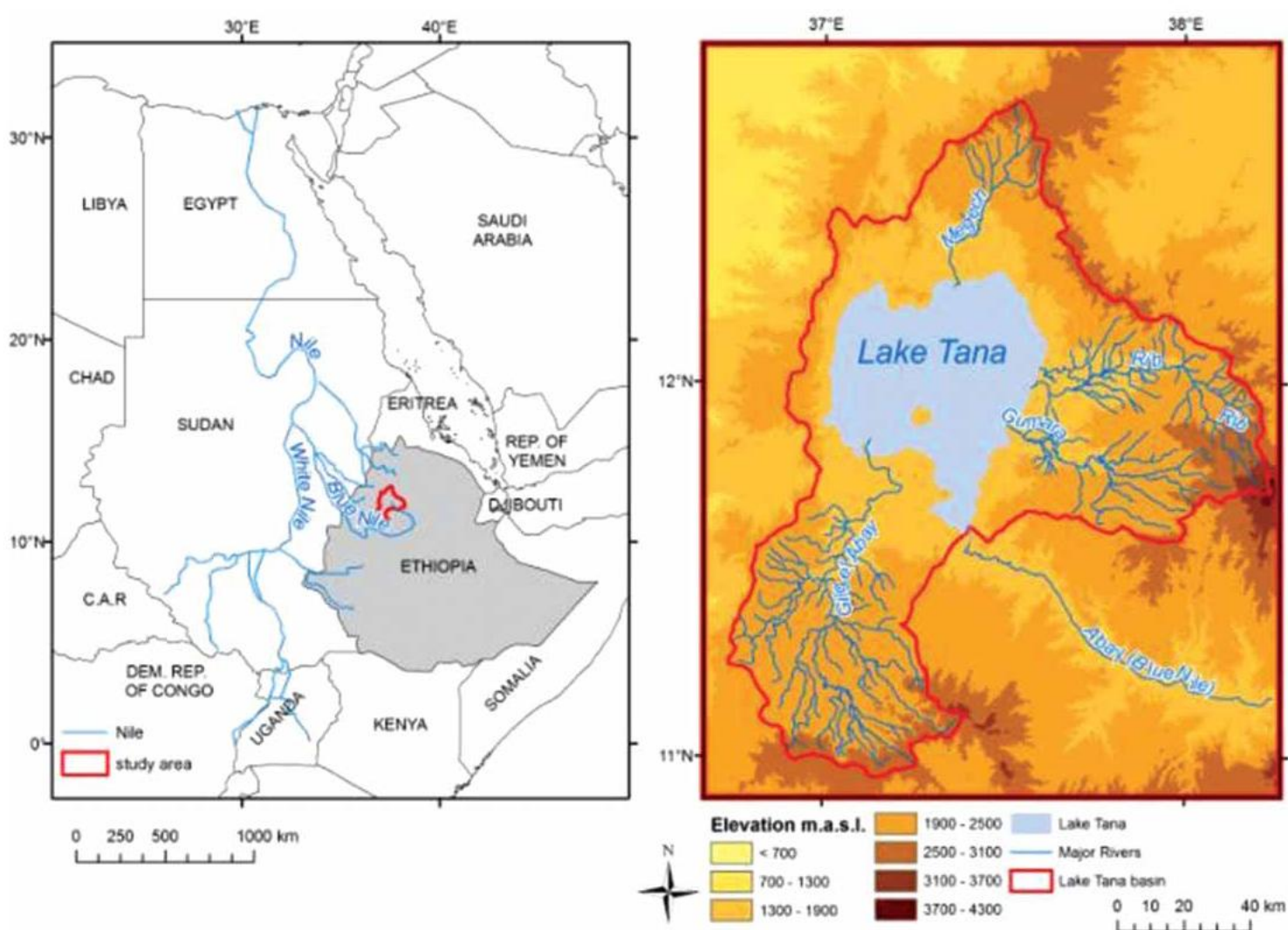

Figure 1. Location of study area a) in Africa and b) on an ASTER DEM (available from http://www.gdem. aster.ersdac.or.jp/).

this water reservoir poses challenges among its users who often have conflicting interests. The most striking example is the conflict between power generation and tourism: hydropower generation sometimes dries out the Blue Nile Falls which draws many tourists. Geopolitical tension between countries depending on Nile water further illustrates this issue.

The Lake Tana basin mainly constitutes lavas that erupted during the Plio-Oligocene through fissures and later through shield volcanoes (Kieffer et al., 2004). During the Pliocene - Holocene, Aden series lavas erupted and formed a volcanic barrier to the south of Lake Tana, which helped to form the present lake (Mohr, 1964). It is, however, argued by Chorowicz et al. (1998) that the Lake Tana basin is formed by a convergence of three grabens, which formed before the mid-Tertiary by deep-slip faults. Chorowicz et al. (1998) also found that fault reactivation occurred in the Late-Miocene-Quaternary period.

The rainy season in the Lake Tana basin occurs from June to September, resulting from the movement of the inter-tropical convergence zone (ITCZ). When the ITCZ is located to the north of the equator, Ethiopia receives moist air masses from the Atlantic and Indian Oceans (Kebede et al., 2006). Mean annual rainfall over the Lake Tana basin is $1421 \mathrm{~mm}$ (Conway, 2000), mean annual air temperature is $20^{\circ} \mathrm{C}$ (Kebede et al., 2006) and mean annual evapotranspiration for the basin is $773 \mathrm{~mm}$ (Setegn, 2008).

The importance of Lake Tana for Ethiopia and for downstream countries warrants the production of a geomorphological map. This map (see Online Supplementary Material) will contribute to a better understanding of (a) the formation of the landscape in the Lake Tana basin, (b) the crucial role that lake fluctuations played in determining the geomorphology of the Lake Tana basin, (c) the magnitude of the current erosion processes and (d) the hydrological balance of Lake Tana. 


\section{Methods}

Geomorphological fieldwork was conducted from July to September 2011 to:

- verify and adjust information held on existing geological maps by Kazmin (1972) and BCEOM (1999)

- map distinct geomorphologic features and entities using handheld global positioning system (GPS) receiver

- assess changes in lake extent by investigating ancient lake beaches including those mentioned by Nilsson (1940)

- map inactive volcanic craters, volcanic plugs and faulted blocks. Mapping was augmented using Google Earth (Poppe, 2012).

The hydrology and some geomorphic landforms were mapped using GeoEye, CNES/SPOT and DigitalGlobe imagery available through Google Earth (accessed from http://www.google.com/ earth/index.html) and ASTER (accessed from http://www.gdem.aster.ersdac.or.jp/). Isobaths have been defined by digitising the bathymetric map by Pietrangeli (1988) and by applying Natural Neighbour interpolation in Esri ArcGIS 9.3.1.

Lake extent variations were analysed using historical maps from 1868 to 1936 (Table 1) and Landsat imagery from 1973 to 2010 available from the US Geological Survey (USGS) (http:// earthexplorer.usgs.gov). The lake was delineated in the Landsat images by using a supervised classification. To test the accuracy of this method, the obtained lake extent was compared to

Table 1. Details about consulted maps.

\begin{tabular}{|c|c|c|c|c|c|}
\hline Holder $(\mathrm{H}) /$ Author $(\mathrm{A})$ & $\begin{array}{c}\text { Source: Aerial } \\
\text { photograph } \\
\text { (AP)/Fieldwork } \\
\text { (F)/Satellite (S) }\end{array}$ & Publication & Scale & Area & Series/Shee \\
\hline $\begin{array}{l}\text { Istituto } \\
\quad \text { Geografico Militare }\end{array}$ & $1868-1885(\mathrm{~F})$ & 1901 & $1: 400,000$ & Gonder region & 693 \\
\hline $\begin{array}{l}\text { Studio Cartog. } \\
\text { G. Giardi - Firenze } \\
\text { (H) M. Checchi (A) }\end{array}$ & $1882(\mathrm{~F})$ & 1913 & $1: 600,000$ & Lake Tana & $2114 / 14 \mathrm{~A} 8$ \\
\hline $\begin{array}{l}\text { Istituto Geografico } \\
\text { Militare }(\mathrm{H})\end{array}$ & $\begin{array}{l}1882 \text { and } \\
\text { later }(\mathrm{F})\end{array}$ & 1934 & $1: 400,000$ & Gonder region & 18 A 6/F9 \\
\hline $\begin{array}{l}\text { Grabham and } \\
\text { Black (A) }\end{array}$ & $1920-1921(\mathrm{~F})$ & 1925 & $1: 500,000$ & $\begin{array}{l}\text { Lake Tana } \\
\text { catchment }\end{array}$ & / \\
\hline Cheesman & $1927(\mathrm{~F})$ & 1936 & $\pm 1: 500,000$ & $\begin{array}{l}\text { Lake Tana } \\
\text { catchment }\end{array}$ & / \\
\hline Kazmin & $?$ & 1972 & $1: 2,000,000$ & Ethiopia & \\
\hline $\begin{array}{l}\text { Ethiopian Mapping } \\
\text { Agency }(\mathrm{H})\end{array}$ & $1987(\mathrm{~S})$ & 1996 & $1: 500,000$ & Bahir Dar & $\begin{array}{c}\text { EMA 3/ } \\
\text { NC- 37-1 }\end{array}$ \\
\hline Studio Pietrangeli (A) & $?$ & 1988 & $1: 200,000$ & Lake Tana & 0801D09A \\
\hline $\begin{array}{l}\text { Ethiopian Mapping } \\
\text { Agency }(\mathrm{H})\end{array}$ & 1988 (AP) & 1996 & $1: 500,000$ & Debre Tabor & $\begin{array}{l}\text { EMA 3/ } \\
\text { NC 37-2 }\end{array}$ \\
\hline $\begin{array}{c}\text { Ethiopian Mapping } \\
\text { Agency }(\mathrm{H})\end{array}$ & $1995(\mathrm{~S})$ & 2001 & $1: 500,000$ & Gondar & $\begin{array}{c}\text { EMA 3/ } \\
\text { ND 37-13 }\end{array}$ \\
\hline $\begin{array}{c}\text { Ethiopian Mapping } \\
\text { Agency }(\mathrm{H})\end{array}$ & $1995(\mathrm{~S})$ & 2001 & $1: 500,000$ & Yifag & $\begin{array}{c}\text { EMA 3/ } \\
\text { ND 37-14 }\end{array}$ \\
\hline BCEOM & $1998(\mathrm{~F})$ & 1999 & $\begin{array}{l}\text { Digital } \\
\text { edition }\end{array}$ & $\begin{array}{l}\text { Lake Tana } \\
\text { basin }\end{array}$ & I \\
\hline
\end{tabular}


lake stage measured at Bahir Dar (south of Lake Tana) lake gauge. A strong correlation was found between the two $\left(R^{2}=0.86, p<0.0001\right)$.

The accuracy of all these different methods is specified on the geomorphological map. More detailed information about the mapping process and accuracies are given by Poppe (2012).

The geomorphological map was designed using colour for both lithology and chronology following Gustavsson, Kolstrup, and Seijmonsbergen (2006). Colour choice was based on standards of the Alpine Geomorphology Research Group (AGRG) (Degraaff, Dejong, Rupke, \& Verhofstad, 1987). The geographic datum used is the WGS 1984 spheroid and the projection is the Universal Transverse Mercator, zone $37 \mathrm{~N}$.

\section{Geomorphological map of Lake Tana basin and its legend}

\subsection{Hydrography}

The hydrogeomorphology of the Lake Tana basin is heterogeneous. The four major rivers are characterised by a succession between bedrock types in their higher reaches, and alluvial types in their lower reaches and floodplains. These alluvial rivers were classified into meandering, anastomosing and braided river types. The river type on the Quaternary Aden series is predominantly braided (see for instance Gumara River between $11.7959^{\circ} \mathrm{N}, 37.6596^{\circ} \mathrm{E}$ and $11.7909^{\circ} \mathrm{N}, 37.6678^{\circ} \mathrm{E}$ ). This can be linked to the strong sediment input in the lake at the delta of the Gilgel Abay river, whose catchment is mainly occupied by Aden series lavas. Palaeohydrography of the basin was not shown on the geomorphological map, but is reported in Poppe (2012)

\subsection{Geomorphology}

The faulted blocks on the western and eastern margin of Lake Tana support the theory of Chorowicz et al. (1998) that the basin is formed by the convergence of three grabens. During fieldwork it was also clear at the Blue Nile Falls that the Blue Nile plunges over a volcanic barrier that consists of more recent lavas: the Aden series (Mohr, 1964). During geomorphologic mapping, evidence was found reconciling both theories. It is argued here that the basin formed by convergence of three grabens during the mid-Tertiary (Chorowicz et al., 1998) and then extended by lava damming.

The West Tana Escarpment (Chorowicz et al., 1998), which is the water divide for a large part of the west of the basin, is an erosional feature - as suggested by Grabham and Black (1925) - because the escarpment is fringed and not straight like a fault. It was therefore formed by water erosion.

\subsection{Materials}

\subsubsection{Igneous rock}

Igneous rocks comprise the Mio-Pliocene 'Trap Series' and the Quaternary 'Aden Series' (Gani, Gani, \& Abdelsalam, 2007; Kazmin, 1972). The Trap series (mainly basalts) extruded from fissures and centres of flood lavas and built up a 500-1500 m thick volcanic pile (Mohr, 1964; Mohr \& Zanettin, 1988). Trap series also contain two shield volcanoes from the Miocene which partially form the water divide on the south-eastern margin of the basin: Mount Choke (3504 m a.s.1.) and Mount Guna (4086 $\mathrm{m}$ a.s.1.). The entire basin consists of these lavas which are outcropping where they are not overlain by the more recent Aden series or by lacustrine deposits.

The Aden series are characterised by the presence of several strombolian volcanoes that are striking features of the landscape (Figure 2). During the field study, it was observed that parts of the outcropping Quaternary Aden series were more intensively weathered than their surrounding Mio-Pliocene Trap series. 




Figure 2. Magma conduit, with lava tube (i.e. a cave, note two persons standing at the entrance) in a strombolian volcano near Merawi. A dyke is also visible within the scoria and the cave is surrounded by volcanic ashes, lapilli and volcanic bombs (in the foreground). Photo taken on $02 / 08 / 11$ by Ludwin Poppe $\left(11.41559^{\circ} \mathrm{N} 37.13596^{\circ} \mathrm{E}\right)$.

\subsubsection{Unconsolidated sediments}

Unconsolidated Quaternary sediments stem from lacustrine, fluvial or hillslope processes. Lacustrine sediments were recognised in the field as black, clearly layered fine sediments which often occur on a large plain or in a drowned valley. These sediments are situated north and east of the lake, where the lake is bordering flat to gently sloping land (Nilsson, 1940). Occurrences of these sediments helped determine the paleoshoreline. Soils formed on these sediments have been analysed by Colot (2012).

Alluvial/colluvial deposits generated from fluvial processes, are locally mixed with slope colluvium. These sediments have a brownish/red colour in the field and are found on slopes and along rivers.

\subsection{Processes}

Variations in the level and extent of Lake Tana, which interfere with geomorphic processes in the basin, were first studied in detail by Nilsson (1940). An ancient maximum lake level was assumed to exist $120 \mathrm{~m}$ above the current lake level. Based on Lamb et al. (2007), we can conclude that such a lake should be at least dated to 15,000 BP. Plotting this assumed level on an ASTER DEM, however, revealed that the present basin cannot support such a high lake level, as the lake would overflow at several locations.

Reinvestigation of ancient lake beaches led to the conclusion that the maximum level of Lake Tana was at $1861 \pm 2.5 \mathrm{~m}$ a.s.l., i.e. $76 \mathrm{~m}$ higher than the present lake level. This conclusion was 


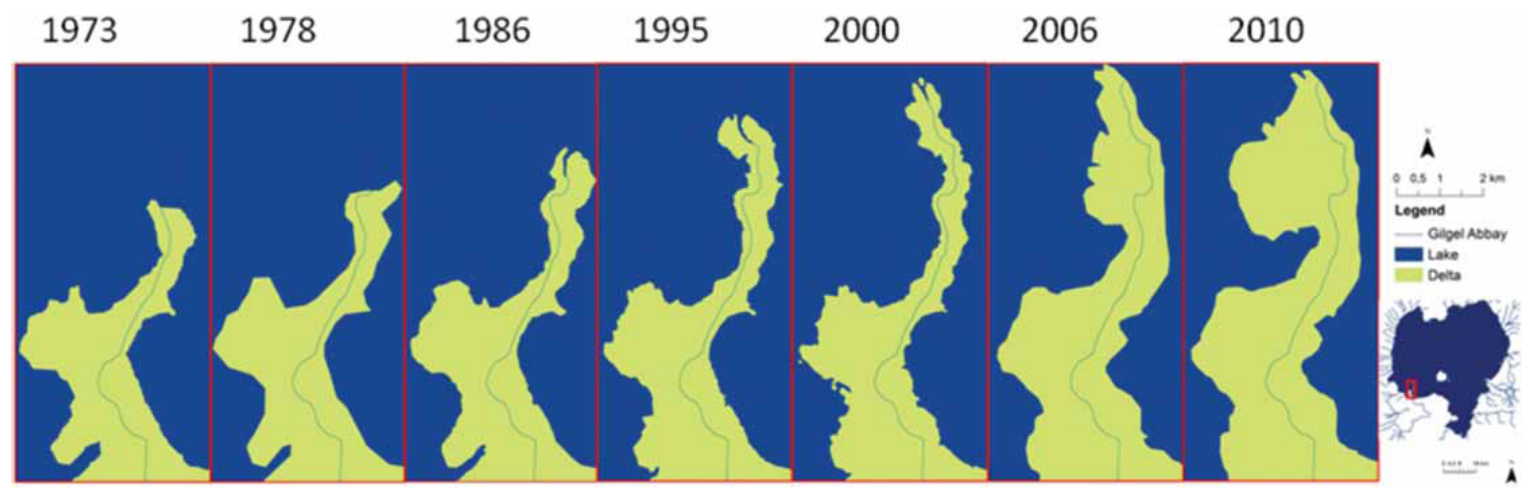

Figure 3. Expansion of Gilgel Abay delta during the period 1973-2010 based on the analysis of Landsat imagery (available from http://earthexplorer.usgs.gov).

drawn based on field evidence of lacustrine deposits at that height. A stage-area curve was calculated for the lake: the equation for lake stage (in $\mathrm{m}$ ) is: $\mathrm{Y}=0.035 \mathrm{X}$ (lake extent in $\mathrm{km}^{2}$ ) +1677 . This corresponds to an extent of $6514 \mathrm{~km}^{2}$ for the ancient maximum lake compared to the present lake extent of $3041 \mathrm{~km}^{2}$.

Recent (twentieth century) changes in lake extent are small: there is no significant pattern, and there are only small coastal changes. These coastal changes have been linked to dominant wind direction (Gasse, 1987), but no structural link with coastal change was revealed. There is, however, a structural link between rivers flowing through the Aden series and river deltas that have increased significantly during the period (1973-2010). Gilgel Abay's entire catchment is located on the Aden series, and it's delta had the greatest increase (Figure 3). It was also noticed that coasts with small cliffs are often linked with a deep lake bottom and present minor coastal changes.

Tectonic processes are indicated on the map by digitising fault lines from Kazmin (1972), and indicating the three grabens that formed the Lake Tana basin. The edges of the grabens are modified from Chorowicz et al. (1998) based on field observations and Google Earth observations.

\section{Conclusions}

The geomorphological map, prepared from fieldwork and the analysis of satellite imagery shows that the Lake Tana basin has changed gradually over time. Eruption of the Trap series was followed by formation of shield volcanoes and then eruption of the Aden series. Not only has this basin been formed by lavas, it has also been shaped by tectonic forces: three grabens formed in the lavas during the mid-Tertiary and Lake Tana is located at their convergence.

The importance of lake level and area fluctuations is shown on the map and is crucial for the history of Lake Tana, especially for long-term variations in lake deposits. Lake Tana has an area of $3041 \mathrm{~km}^{2}$ and is at $1785 \mathrm{~m}$ a.s.l., whereas at $>15,000 \mathrm{BP}$ it had an area of $6514 \mathrm{~km}^{2}$, and was located at $1861 \mathrm{~m}$ a.s.1.. In the more recent period (1868-2010) the lake level did not show important fluctuations. Coastal erosion and sediment deposition has also been negligible, except at Gilgel Abay delta, which shows considerable change during the last 40 years and particularly in the last 15 years, in response to intense soil erosion in the catchment.

\section{Software}

For conducting the supervised classification of the Landsat images, Erdas Image Analyst was used with Esri ArcGIS 9.3.1. The latter was used for the construction of the geomorphological map. 


\section{Acknowledgements}

The authors like to thank the WASE-TANA project, funded by VLIR, Belgium as well as the project car driver Miniychl Alem, translator Wudalew Admasu, Ruben Maes and Charlotte Colot for their help. R. Neil Munro and Paolo Billi have provided historical maps.

\section{References}

BCEOM (1999). Abay River Basin Integrated Development Master Plan Project: Main Report. Addis Ababa, Federal Democratic Republic of Ethiopia.

Chorowicz, J., Collet, B., Bonavia, F. F., Mohr, P., Parrot, J. F., \& Korme, T. (1998). The Tana basin, Ethiopia: Intra-plateau uplift, rifting and subsidence. Tectonophysics, 295(3-4), 351-367.

Colot, C. (2012). Soil-Landscape Relation at Regional Scale in Lake Tana Basin (Ethiopia). MSc thesis, Department of Soil and Water Management, KULeuven, Belgium.

Conway, D. (2000). The climate and hydrology of the Upper Blue Nile river. The Geographical Journal, $166(1), 49-62$.

Degraaff, L. W. S., Dejong, M. G. G., Rupke, J., \& Verhofstad, J. (1987). A geomorphological mapping system at scale 1:10,000 for Mountainous Areas. Zeitschrift Fur Geomorphologie, 31(2), 229-242.

Gani, N. D. S., Gani, M. R., \& Abdelsalam, M. G. (2007). Blue Nile incision on the Ethiopian Plateau: Pulsed plateau growth, Pliocene uplift and hominin evolution. GSA Today, 17, 4-11.

Gasse, F. (1987). Ethiopie et Djibouti. African Wetlands and Shallow Water Bodies: Zones humides et lacs peu profonds d'Afrique (pp. 300-311). M. J. Burgis, \& J. J. Symoens (Eds.), Paris: ORSTOM.

Grabham, G. W., \& Black, R. P. (1925). Report of the mission to lake Tana1920-1921. Cairo: Government Press.

Gustavsson, M., Kolstrup, E., \& Seijmonsbergen, A. C. (2006). A new symbol-and-GIS based detailed geomorphological mapping system: Renewal of a scientific discipline for understanding landscape development. Geomorphology, 77(1-2), 90-111.

Kazmin, V. (1972). Geological map of Ethiopia. Addis Ababa: Ministry of Mines.

Kebede, S., Travi, Y., Alemayehu, T., \& Marc, V. (2006). Water balance of Lake Tana and its sensitivity to fluctuations in rainfall, Blue Nile Basin, Ethiopia. Journal of Hydrology, 316, 233-247.

Kieffer, B., Arndt, N., Lapierre, H., Bastien, F., Bosch, D., Pecher, A., ... Meugniot, C. (2004). Flood and shield basalts from Ethiopia: Magmas from the African superswell. Journal of Petrology, 45(4), $793-834$.

Lamb, H. F., Bates, C. R., Coombes, P. V., Marshall, M. H., Umer, M., Davies, S. J., \& Dejen, E. (2007). Late Pleistocene desiccation of Lake Tana, source of the Blue Nile. Quaternary Science Reviews, 26(3-4), 287-299.

Mohr, P., \& Zanettin, B. (1988). The Ethiopian flood Basalt province. In J. D. Macdougall (Ed.), Continental flood Basalts (pp. 63-110). Dordrecht: Kluwer Academic Publishers.

Mohr, P. A. (1964). The geology of Ethiopia. Addis Ababa: University College of Addis Ababa.

Nilsson, E. (1940). Ancient changes of climate in British East Africa and Abyssinia. A study of Ancient Lakes and Glaciers. Geografiska Annaler, 22, 1-79.

Pietrangeli (1988). Bathymetry of lake Tana. Unpublished report. Studio Pietrangeli, Italy.

Poppe, L. (2012). Geomorphology of lake Tana basin, Ethiopia. MSc thesis, Department of Geography, UGent, Belgium.

Setegn, S. G. (2008). Hydrological and sediment yield modelling in Lake Tana Basin, Blue Nile Ethiopia. MSc thesis, Department of Land and Water Resources Engineering, Royal institute of Technology (KTH), Stockholm. 


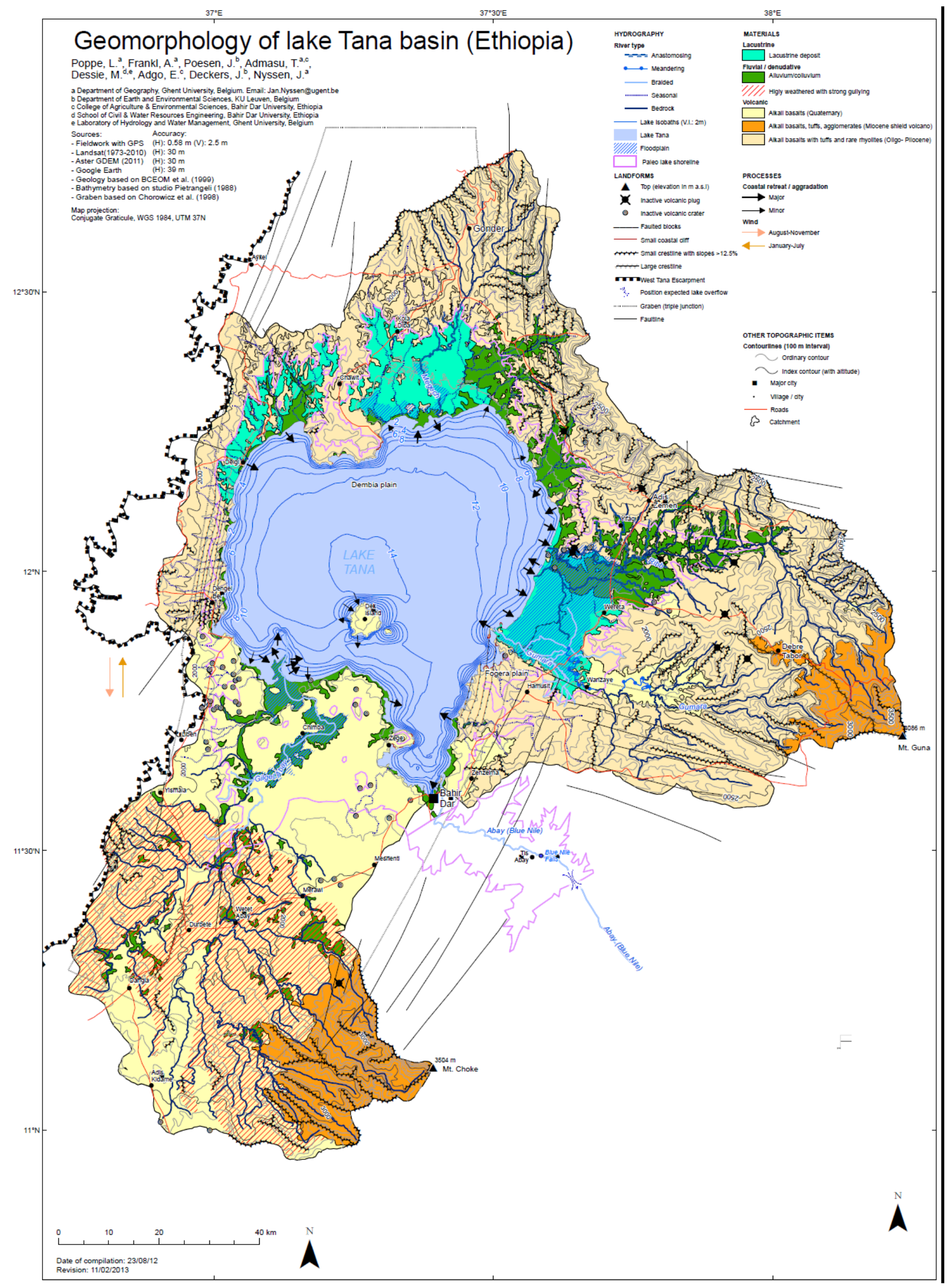

